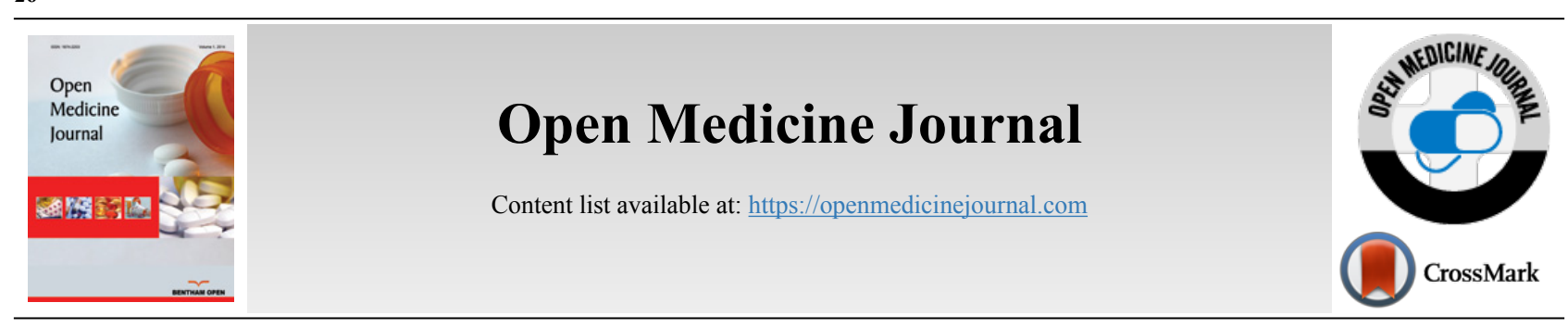

RESEARCH ARTICLE

\title{
Gender Differences and Treatment Outcome among Drug Induced Hepatotoxicity Tuberculosis Patients
}

\author{
Kamini Nadarajah ${ }^{1}$, Amer Hayat khan ${ }^{1, *}$, Irfhan $\mathrm{Ali}^{1,2}$, Raja Ahsan Aftab ${ }^{1,3,{ }^{*}}$ and Imam Shaik ${ }^{4}$ \\ ${ }^{I}$ Department of Clinical Pharmacy, School of Pharmaceutical Sciences Universiti Sains Malaysia, 11800 Penang, Malaysia \\ ${ }^{2}$ Department of Respiratory Medicine, Penang General Hospital, Penang, Malaysia \\ ${ }^{3}$ School of Pharmacy, Taylor's University, Subang Jaya, Selangor, Malaysia \\ ${ }^{4}$ School of Medicine, Taylor's University, Subang Jaya, Selangor, Malaysia
}

\begin{abstract}
:
Aims and Objective:

The aim of the current manuscript is to determine the association between gender differences and drug-induced hepatotoxicity among patients receiving anti-tuberculosis therapy and to determine the outcome of the treatment.

Methods:

A retrospective observational study was conducted among tuberculosis patients at Respiratory Clinic of Penang General Hospital (PGH) and Bukit Mertajam Hospital. A validated data collection instrument was used to collect patients' demographic and clinical data confirmation of drug induced hepatotoxicity among tuberculosis patients was based on biochemical criteria which included 3 fold increase in liver enzymes in response to anti TB medication. All results were analyzed through SPSS version 20.

Results:

The study subjects were predominantly males 146 (76.8\%) than females $44(23.2 \%)$. Drug-induced hepatotoxicity with anti-tuberculosis drugs was observed the most among Chinese 90 (47\%) ethnicity. Eighty-five (72\%) male and 33 female (28\%) tuberculosis drug-induced (TB-DIH) patients had a successful treatment outcome. Female patients had a statistically significant positive association with successful TB-DIH treatment outcomes $(\mathrm{OR}=1.83,0.988-3.39095 \% \mathrm{CI})$. Upon multivariate analysis, Indian ethnicity $(\mathrm{OR}=0.173, \mathrm{p}=0.024)$, patients with relapse of Tuberculosis $(\mathrm{TB})$ $(\mathrm{OR}=0.332, \mathrm{p}=0.032)$ and Human Immune Virus $(\mathrm{HIV})(\mathrm{OR}=0.217, \mathrm{p}=0.027)$ were less likely to have successful TB-DIH treatment outcomes.

Conclusion:

Female Tuberculosis Drug Induced Hepatotoxicity (TB DIH) patients were more likely to have successful treatment outcomes. A number of factors such as Indian ethnicity, patients with relapse of Tuberculosis (TB) and patients with Human Immune Virus (HIV) were less likely to have successful TB DIH treatment outcomes.
\end{abstract}

Keywords: Gender differences, Drug-induced hepatotoxicity, Tuberculosis, Treatment outcomes, MDR-TB, Anti-tuberculosis therapy.

\begin{tabular}{|l|l|l|r} 
Article History & Received: February 09, 2019 & Revised: April 05, 2019 & Accepted: April 19, 2019
\end{tabular}

\section{INTRODUCTION}

Tuberculosis (TB) is one of the pre-historical diseases known to mankind and still remains the leading single infectious cause of death among adults [1]. It is believed that one in three is either infected with Mycobacterium tuberculosis, or is at risk of developing the disease [2]. The

\footnotetext{
* Address correspondence to these authors at the Department of Clinical Pharmacy, School of Pharmaceutical Sciences Universiti Sains Malaysia, 11800 Penang, Malaysia and School of Pharmacy, Taylor's University Jalan Taylors, Subang Jaya, Selangor Malaysia; Tel: 0060-175453546, 0060-172554387;

E-mails: dramer2006@gmail.com, rajaahsan.aftab@taylors.edu.my
}

WHO classified Malaysia as an 'intermediate' TB burden country in 2004 . In the last 20 years, the incidence rate has been stagnating, although there was a slight upward trend between 2004 and 2006, from 60.3 to 62.6 per 100,000 [3].

The global increasing threat of drug resistance and multidrug resistant TB (MDR-TB) is another important reason for the TB epidemic. In 2008, MDR-TB emerged with an estimated 440,000 cases globally [2]. Almost $50 \%$ of MDR-TB cases worldwide are estimated to occur in China and India [2]. The non-standardised and interrupted chemotherapy treatment 


\section{of TB is the main risk factor for MDR-TB [4].}

The experience of the WHO since 1997 in assisting high TB burden countries to set up standardised TB surveillance systems shows that globally, men account for a higher proportion of notified TB cases (63\% or 64\%) [5]. Data on sex differentials in TB from some Western European countries during the period from 1930 to 1950, when the disease burden there was still high, present a different picture: no significant difference in TB between the sexes in childhood and preadolescence, a higher incidence in female than in male adolescents and young adults, and a higher incidence in men than in women over 40 years of age. Studies in various countries have also shown that progression from TB infection to disease is likely to be faster for women compared to men in their reproductive years, and faster for men over 40 years of age [6].

The most frequent adverse effects of anti-tuberculosis treatment are hepatotoxicity, skin reactions, and gastrointestinal and neurological disorders [7]. Hepatotoxicity is the most serious adverse effect of anti-tuberculosis therapy [8]. Anti-tuberculosis drug-induced hepatotoxicity (ATDH) causes substantial morbidity and mortality and diminishes treatment effectiveness. Asymptomatic transaminase elevations are common during anti-tuberculosis treatment, and hepatotoxicity can be fatal if not recognized early and when therapy is not interrupted in time. Isoniazid, rifampicin and pyrazinamide are potentially hepatotoxic drugs. The incidence of ATDH during standard multidrug TB treatment has been variably reported as between $2 \%$ and $28 \%$. This rate depends on the investigators' definition of hepatotoxicity as well as the population studied [9].

Tuberculosis drugs are commonly safe. However, in certain scenarios, the use of these drugs may cause some problems such as the occurrence of ADRs. The purpose of the current manuscript is to determine the association between gender differences and drug-induced hepatotoxicity in antituberculosis therapy in Bukit Mertajam Hospital and Penang Hospital (PGH), Malaysia.

\section{METHODOLOGY}

\subsection{Study Design \& Location}

A retrospective observational study was conducted among the tuberculosis patients at the Respiratory Clinic of Penang General Hospital (PGH) and Bukit Mertajam Hospital. The study ran from January 2007 until September 2013.

\subsection{Study Population}

The Malaysian population stands at over 28 million. The country is separated by the South China Sea into two regions, Peninsular Malaysia and Malaysian Borneo (also known as East Malaysia). The study location was Penang, located in West Malaysia (Peninsular Malaysia) with a population of $1,503,000$ and an area of $1,046 \mathrm{~km}^{2}$. The study population included individuals (males and females) of all age groups who were in Penang during the study period and were suffering from confirmed tuberculosis.

\subsection{Sampling Technique}

The sampling technique used in this study was the universal sampling technique: collecting patients' TB records available in the Chest Clinic. No information gathered directly from patients in the ward. Patients' records were sorted, patients with inadequate medical records were allowed to complete analysis, and patients receiving other potentially hepatotoxic medications concurrent with the anti-TB treatment were excluded.

\subsection{Criteria for the Confirmation of Drug-induced Hepatotoxicity Among Tuberculosis Patients}

The confirmation of drug induced hepatotoxicity among tuberculosis patients was based on biochemical criteria and clinical judgment of clinician. The biochemical criteria included the increased level of liver enzymes in response to anti TB medication and included the presence of one of the following conditions that include rise in 3 fold times the upper limit of ALT and AST along with nausea, vomiting and jaundice, and normalization of liver enzymes and the resolution of sign and symptoms of hepatotoxicity after withdrawal of anti-Tb drugs [10].

\subsection{Treatment Outcome Evaluation}

A TB patient is defined cured if he/she is smear negative one month prior to the completion of treatment. Treatment outcomes were evaluated on the basis of smear testing at the end of treatment [11]

\subsection{Data Collection}

The record of each patient was kept in an envelope which was referred to as the patient's wallet or patient's case. Besides containing the record file of the patient drug therapy, the wallet contained x-ray films, laboratory test results and referral letters from doctors. All types of drug therapies are noted here, as well as other complications. Drug-related problems, their sensitivity on the basis of clinical signs and symptoms, and the management of these problems, were also recorded.

\subsection{Data Analysis}

Each data collection form was assigned a serial number to ensure traceability. Coding of the responses was carried out and the data was entered into a computer and analyzed using Statistical Package for the Social Sciences (SPSS) version 20.0 programme for Windows (SPSS, Inc., Chicago, IL, USA).

The data was analyzed by using parametric and nonparametric statistics such as descriptive, Chi-square, and independent " $t$ " tests. Descriptive tests were used to describe the frequencies of patients and their lab tests. Chi-square tests were used to find the associations between the nominal variables (demographic factors such as gender, race and age) and disease. Logistic regression was used to adjust OR and was used to indicate the significance of association. A P-value < 0.05 was considered statistically significant.

\subsection{Ethical Consideration}

Ethical clearance was secured from the School of Pharma- 
ceutical Sciences, University Sains Malaysia. Permission to proceed with the study protocol was obtained from the Clinical Research Centre (CRC) Penang Hospital, Pulau Pinang.

\section{RESULTS}

Table 1 demonstrates the socio-demographic characteristics of the study subjects at the time of diagnosis. The study subjects were predominant males $(n=146,76.8 \%)$, with only $23.2 \%$ females $(n=44)$. The mean body weight was $45.83 \mathrm{~kg}$. The age of the patients was divided into two groups as shown in Table 1 . The majority of patients $(n=153,80.5 \%)$ were above 35 years of age, with 37 patients (19.5\%) below 35 years of age. The mean age was 46.92 years. There was no significant difference between both groups $(p=0.136)$.
Malaysia is a multi-ethnic country with three large race groups: Malay, Chinese and Indian. Hence in this study, the race is categorized into four groups: Malay, Chinese, Indian and other. Other races here stand for patients from other countries: Indonesia, Myanmar, Bangladesh and Nepal. The occurrence of DIH with anti-tubercular is as follows: Malay 64 (34\%), Chinese 90 (47\%), Indian 25 (13\%), and others 11 $(6 \%)$, which shows non-significant differences $(\mathrm{p}=0.239)$.

A significantly higher percentage of these patients was from urban areas $(n=151,79.5 \%)$, and particularly unmarried males $(n=99,81.8 \%)$. There were no significant differences in the employment status $(\mathrm{p}=0.448)$ and education level $(p=0.247)$.

Table 1. Socio-Demographic Status of TB-Drug Induced Hepatitis Patients.

\begin{tabular}{|c|c|c|c|c|}
\hline \multirow{3}{*}{ Variables } & \multicolumn{2}{|c|}{ Gender } & \multirow{3}{*}{$\mathbf{X}^{2}$} & \multirow{3}{*}{ P-value } \\
\hline & Male & Female & & \\
\hline & $n(\%)$ & $n(\%)$ & & \\
\hline No of patients & $146(76.8)$ & $44(23.2)$ & & \\
\hline \multicolumn{5}{|l|}{ Age Group } \\
\hline Mean Age (Years) & $47.49 \pm 14.28$ & $45.0 \pm 14.96$ & & \\
\hline$\leq 35$ & $25(67.6)$ & $12(32.4)$ & \multirow{2}{*}{2.221} & \multirow{2}{*}{$0.136^{*}$} \\
\hline$>35$ & $121(79.1)$ & $32(20.9)$ & & \\
\hline \multicolumn{5}{|l|}{ Body Weight (Kg) } \\
\hline Mean Weight & $45.63 \pm 10.99$ & 46.4913 .83 & & \\
\hline \multicolumn{5}{|l|}{ Ethnicity } \\
\hline Malay & $45(70.3)$ & $19(29.7)$ & \multirow{4}{*}{4.215} & \multirow{4}{*}{$0.239^{*}$} \\
\hline Chinese & $74(82.2)$ & $16(17.8)$ & & \\
\hline Indian & $20(80)$ & $5(20)$ & & \\
\hline Others & $7(63.6)$ & $4(36.4)$ & & \\
\hline \multicolumn{5}{|l|}{ Residence } \\
\hline Urban & $108(71.5)$ & $43(28.5)$ & \multirow{2}{*}{11.695} & \multirow{2}{*}{$0.001 *$} \\
\hline Rural & $38(97.4)$ & $1(2.6)$ & & \\
\hline \multicolumn{5}{|l|}{ Marital Status } \\
\hline Married & $47(68.1)$ & $22(31.9)$ & \multirow{2}{*}{4.636} & \multirow{2}{*}{$0.31^{*}$} \\
\hline Unmarried & $99(81.8)$ & $22(18.2)$ & & \\
\hline \multicolumn{5}{|l|}{ Employment Status } \\
\hline Employed & $48(78.7)$ & $13(21.3)$ & \multirow{3}{*}{1.606} & \multirow{3}{*}{$0.448^{*}$} \\
\hline Unemployed & $82(78.1)$ & $23(21.9)$ & & \\
\hline Unknown & $16(66.7)$ & $8(33.3)$ & & \\
\hline \multicolumn{5}{|l|}{ Education Level } \\
\hline Formal education & $137(77.8)$ & $39(22.2)$ & \multirow{2}{*}{1.339} & \multirow{2}{*}{$0.247^{*}$} \\
\hline No formal education & $9(64.3)$ & $5(35.7)$ & & \\
\hline \multicolumn{5}{|l|}{ Smoking Habit } \\
\hline Yes & $97(95.1)$ & $5(4.9)$ & \multirow{2}{*}{41.246} & \multirow{2}{*}{$<0.001^{*}$} \\
\hline No & $49(55.7)$ & $39(44.3)$ & & \\
\hline \multicolumn{5}{|l|}{ Alcohol Drinking Habit } \\
\hline Yes & $37(97.4)$ & $1(2.6)$ & \multirow{2}{*}{11.246} & $0001 *$ \\
\hline No & $109(95.6)$ & $43(28.5)$ & & $0.001^{*}$ \\
\hline IVDU & & & & \\
\hline Yes & $43(95.6)$ & $2(4.4)$ & 11604 & $0001 *$ \\
\hline No & $103(71.0)$ & $42(29.0)$ & 11.004 & $0.001^{\circ}$ \\
\hline
\end{tabular}

*Chi-square *Fisher-exact test 
In this study, male patients were found to be more strongly associated with smoking (95.1\%) being one of the main risk behaviours $(\mathrm{p}<0.001)$. Moreover, non-alcoholic $(\mathrm{n}=109$, 95.6\%) and non-IVDU $(\mathrm{n}=103,71.0 \%)$ male patients showed significant differences $(\mathrm{p}=0.001)$ (Table 1).

Majority of the cases were newly registered $(n=163$, $85.8 \%)$; and $27(14.2 \%)$ were relapse cases. Positive for sputum smear for M.tuberculosis showed similar results in this study as illustrated in Table 2. However, patients with nondiabetes mellitus history $(\mathrm{n}=130,79.3 \%)$ and non- HIV/AIDS history $(\mathrm{n}=107,72.8 \%)$ had significant differences $(\mathrm{p}<0.05)$ as shown in Table 2.

$85(72 \%)$ male and $33(28 \%)$ female patients had a successful treatment outcome. Statistically, patients' gender had a significant association $(\mathrm{p}=0.044)$ with treatment outcome. It is also shown that being a female has a statistically significant positive association with successful treatment outcome (OR=1.83, 0.988-3.390 95\% CI) (Table 3).

In univariate analysis, patients with relapse $\mathrm{TB}(\mathrm{OR}=$ $0.297, \mathrm{P}$-value $=0.006)$, co-morbidities $(\mathrm{OR}=0.501, \mathrm{P}$-value $=$ $0.028)$ and $\mathrm{HIV}(\mathrm{OR}=0.346, \mathrm{P}$-value $=0.004)$ had statistically significant negative associations with successful treatment outcomes (Table 4).

Upon multivariate analysis, successful treatment outcome was observed in smokers $(\mathrm{OR}=2.345, \mathrm{P}$-value $=0.033)$, whereas Indian ethnicity $(\mathrm{OR}=0.173, \mathrm{P}$-value $=0.024)$ and patients with relapse TB $(\mathrm{OR}=0.332, \mathrm{P}$-value $=0.032)$ and $\mathrm{HIV}(\mathrm{OR}=0.217, \mathrm{P}$-value $=0.027)$ were less likely to have successful treatment outcomes (Table 5).

Table 2. Patients clinical characteristic.

\begin{tabular}{|c|c|c|c|c|}
\hline \multirow{3}{*}{ Variables } & \multicolumn{2}{|c|}{ Gender } & \multirow{3}{*}{$\mathbf{X}^{2}$} & \multirow{3}{*}{ P-value } \\
\hline & Male & Female & & \\
\hline & $n(\%)$ & n(\%) & & \\
\hline \multicolumn{5}{|l|}{ TB case } \\
\hline New TB Case & $122(74.8)$ & $41(25.2)$ & \multirow{2}{*}{2.567} & \multirow{2}{*}{$0.109 *$} \\
\hline Relapse TB Case & $24(88.9)$ & $3(11.1)$ & & \\
\hline \multicolumn{5}{|l|}{ TB Types } \\
\hline PTB & $119(79.3)$ & $31(20.7)$ & \multirow{3}{*}{4.733} & \multirow{3}{*}{$0.094 *$} \\
\hline Extra PTB & $20(62.5)$ & $12(37.5)$ & & \\
\hline Both (PTB with Extra PTB) & $7(87.5)$ & $1(12.5)$ & & \\
\hline \multicolumn{5}{|l|}{ Smear Type } \\
\hline Smear +ve & $123(78.3)$ & $34(21.7)$ & \multirow{2}{*}{1.146} & \multirow{2}{*}{$0.284^{*}$} \\
\hline Smear-ve & $23(69.7)$ & $10(30.3)$ & & \\
\hline \multicolumn{5}{|l|}{ TB DM } \\
\hline Yes & $16(61.5)$ & $10(38.5)$ & \multirow{2}{*}{3.964} & \multirow{2}{*}{$0.046^{*}$} \\
\hline No & $130(79.3)$ & $34(20.7)$ & & \\
\hline \multicolumn{5}{|l|}{ TB HIV/AIDS } \\
\hline Yes & $39(90.7)$ & $4(9.3)$ & \multirow{2}{*}{5.996} & \multirow{2}{*}{$0.014 *$} \\
\hline No & $107(72.8)$ & $40(27.2)$ & & \\
\hline
\end{tabular}

*Chi-square *Fisher-exact test

Table 3. Treatment outcome.

\begin{tabular}{|c|c|c|c|c|c|}
\hline \multirow{3}{*}{ Results } & \multicolumn{2}{|c|}{ Gender } & \multirow{3}{*}{ OR } & \multirow{3}{*}{$95 \%$ CI } & \multirow{3}{*}{ p-value } \\
\hline & Male & Female & & & \\
\hline & n (\%) & n (\%) & & & \\
\hline Successively treated & $85(72.0)$ & $33(28.0)$ & \multirow{2}{*}{1.83} & \multirow{2}{*}{$0.988-3.390$} & \multirow{2}{*}{0.044} \\
\hline Un-Successfully treated & $61(84.7)$ & $11(15.3)$ & & & \\
\hline
\end{tabular}

Table 4. Univariate analysis of predictors of treatment outcomes.

\begin{tabular}{|l|c|r|c|c|c|}
\hline \multicolumn{1}{|c|}{ Variable } & \multicolumn{2}{|c|}{$\begin{array}{c}\text { Treatment outcome } \\
\text { Successful unsuccessful }\end{array}$} & 95\% CI & Odds ratio & p-value \\
\hline $\begin{array}{l}\text { Gender } \\
\text { Male } \\
\text { Female }\end{array}$ & $\begin{array}{l}\text { (No) } \\
\text { S2 }(59.9)\end{array}$ & $\begin{array}{r}55(40.1) \\
10(24.4)\end{array}$ & $\begin{array}{c}0.218-1.060 \\
\text { Referent }\end{array}$ & 0.481 & 0.070 \\
\hline
\end{tabular}


(Table 4) contd.....

\begin{tabular}{|c|c|c|c|c|c|}
\hline \multirow{2}{*}{$\begin{array}{ll} & \text { Variable } \\
\text { Age (years) } \\
\leq 40 \\
>40 \\
\end{array}$} & \multicolumn{2}{|c|}{$\begin{array}{l}\frac{\text { Treatment outcome }}{(\text { No. \%) }} \\
\text { Successful unsuccessful }\end{array}$} & \multirow{2}{*}{$\begin{array}{c}\mathbf{9 5 \%} \text { CI } \\
\begin{array}{c}0.674-2.288 \\
\text { Referent }\end{array}\end{array}$} & \multirow{2}{*}{$\begin{array}{c}\text { Odds ratio } \\
1.242\end{array}$} & \multirow{2}{*}{$\begin{array}{c}\text { p-value } \\
0.488\end{array}$} \\
\hline & $\begin{array}{l}53(60.9) \\
60(65.9)\end{array}$ & $\begin{array}{l}34(39.1) \\
31(34.1)\end{array}$ & & & \\
\hline $\begin{array}{l}\text { Weight }(\mathrm{Kg}) \\
>60 \\
31-60 \\
\leq 30\end{array}$ & $\begin{array}{c}9(75.0) \\
101(63.1) \\
3(50.0)\end{array}$ & $\begin{array}{c}3(25.0) \\
59(36.9) \\
3(50.0)\end{array}$ & $\begin{array}{c}0.380-23.679 \\
0.335-8.756 \\
\text { Referent }\end{array}$ & $\begin{array}{l}3.000 \\
1.712\end{array}$ & $\begin{array}{l}0.297 \\
0.519\end{array}$ \\
\hline $\begin{array}{l}\text { Ethnicity } \\
\text { Chinese } \\
\text { Indian } \\
\text { Other } \\
\text { Malay } \\
\end{array}$ & $\begin{array}{l}49(59.0) \\
13(54.2) \\
5(45.5) \\
46(76.7)\end{array}$ & $\begin{array}{c}34(41.0) \\
11(45.8) \\
6(54.5) \\
14(23.3)\end{array}$ & $\begin{array}{c}0.378-1.288 \\
0.268-1.521 \\
0.133-1.555 \\
\text { Referent }\end{array}$ & $\begin{array}{l}0.698 \\
0.638 \\
0.455\end{array}$ & $\begin{array}{l}0.250 \\
0.311 \\
0.209\end{array}$ \\
\hline $\begin{array}{l}\text { Residence } \\
\text { Rural } \\
\text { Urban }\end{array}$ & $\begin{array}{l}21(55.3) \\
92(65.7)\end{array}$ & $\begin{array}{l}17(44.7) \\
48(34.3)\end{array}$ & $\begin{array}{c}0.311-1.355 \\
\text { Referent }\end{array}$ & 0.645 & 0.237 \\
\hline $\begin{array}{l}\text { Marital status } \\
\text { Married } \\
\text { Unmarried }\end{array}$ & $\begin{array}{l}74(65.5) \\
39(60.0)\end{array}$ & $\begin{array}{l}39(34.5) \\
26(40.0)\end{array}$ & $\begin{array}{c}0.674-2.375 \\
\text { Referent }\end{array}$ & 1.265 & 0.465 \\
\hline $\begin{array}{l}\text { Employment status } \\
\text { Yes } \\
\text { No }\end{array}$ & $\begin{array}{l}63(63.0) \\
50(64.1)\end{array}$ & $\begin{array}{l}37(37.0) \\
28(35.9)\end{array}$ & $\begin{array}{c}0.515-1.765 \\
\text { Referent }\end{array}$ & 0.954 & 0.880 \\
\hline $\begin{array}{l}\text { Smoking } \\
\text { Yes } \\
\text { No } \\
\end{array}$ & $\begin{array}{l}65(67.7) \\
48(58.5)\end{array}$ & $\begin{array}{l}31(32.3) \\
34(41.5)\end{array}$ & $\begin{array}{c}0.804-2.742 \\
\text { Referent }\end{array}$ & 1.485 & 0.206 \\
\hline $\begin{array}{l}\text { Alcohol drinking } \\
\text { Yes } \\
\text { No }\end{array}$ & $\begin{array}{l}18(51.4) \\
95(66.4)\end{array}$ & $\begin{array}{l}17 \text { (48.6) } \\
48(33.6)\end{array}$ & $\begin{array}{c}0.253-1.131 \\
\text { Referent }\end{array}$ & 0.535 & 0.101 \\
\hline $\begin{array}{l}\text { Intravenous drug use } \\
\text { Yes } \\
\text { No }\end{array}$ & $\begin{array}{l}26(60.5) \\
87(64.4)\end{array}$ & $\begin{array}{l}17(39.5) \\
48(35.6)\end{array}$ & $\begin{array}{c}0.417-1.709 \\
\text { Referent }\end{array}$ & 0.844 & 0.637 \\
\hline $\begin{array}{l}\text { TB case } \\
\text { Relapse } \\
\text { New case }\end{array}$ & $\begin{array}{c}10(38.5) \\
103(67.8)\end{array}$ & $\begin{array}{l}16(61.5) \\
49(32.2)\end{array}$ & $\begin{array}{c}0.126-0.703 \\
\text { Referent }\end{array}$ & 0.297 & $0.006^{*}$ \\
\hline $\begin{array}{l}\text { TB location } \\
\text { E-PTB } \\
\text { PTB }+ \text { E-PTB } \\
\text { PTB }\end{array}$ & $\begin{array}{c}15(53.6) \\
7(87.5) \\
91(64.1)\end{array}$ & $\begin{array}{c}13(46.4) \\
1(12.5) \\
51(35.9)\end{array}$ & $\begin{array}{c}0.271-1.384 \\
0.508-35.145 \\
\text { Referent }\end{array}$ & $\begin{array}{l}0.612 \\
4.226\end{array}$ & $\begin{array}{l}0.238 \\
0.182\end{array}$ \\
\hline $\begin{array}{l}\text { Co-morbidity } \\
\text { Yes } \\
\text { No }\end{array}$ & $\begin{array}{l}45(54.9) \\
68(70.8)\end{array}$ & $\begin{array}{l}37(45.1) \\
28(29.2)\end{array}$ & $\begin{array}{c}0.270-0.930 \\
\text { Referent }\end{array}$ & 0.501 & $0.028 *$ \\
\hline $\begin{array}{l}\text { Diabetes Mellitus } \\
\text { Yes } \\
\text { No }\end{array}$ & $\begin{array}{l}15(57.7) \\
98(64.5)\end{array}$ & $\begin{array}{l}11(42.3) \\
54(35.5)\end{array}$ & $\begin{array}{c}0.322-1.751 \\
\text { Referent }\end{array}$ & 0.751 & 0.508 \\
\hline $\begin{array}{l}\text { HIV positive } \\
\text { Yes } \\
\text { No }\end{array}$ & $\begin{array}{l}17(43.6) \\
96(69.1)\end{array}$ & $\begin{array}{l}22(56.4) \\
43(30.9)\end{array}$ & $\begin{array}{c}0.167-0.717 \\
\text { Referent }\end{array}$ & 0.346 & $0.004 *$ \\
\hline
\end{tabular}

CI, Confidence Interval; E-PTB, Extra-Pulmonary TB; HIV, Human Immunodefiencey Virus; TB, Tuberculosis

Table 5. Multivariate analysis of predictors of treatment outcome.

\begin{tabular}{|l|l|l|l|c|c|}
\hline Variables & \multicolumn{1}{|c|}{ B } & \multicolumn{1}{|c|}{ SE } & \multicolumn{1}{c|}{ 95\% CI } & Odds ratio & P-value \\
\hline Indian ethnicity & -1.753 & 0.775 & $0.038-0.792$ & 0.173 \\
\hline Relapse TB case & -1.103 & 0.515 & $0.121-0.910$ & 0.34 \\
\hline HIV positive & -1.530 & 0.694 & $0.056-0.843$ & 0.032 \\
\hline Smoking & 0.852 & 0.401 & $1.069-5.141$ & 0.027 & 0.217 \\
\hline
\end{tabular}

B, beta; CI, Confidence Interval; HIV, Human Immunodefiencey Virus; SE, Standard Error; TB, Tuberculosis

\section{DISCUSSION}

The use of a multi-drug regimen for the treatment of TB, such as the combination of INH, RIF and PZA, has been associated with an increased incidence of hepatotoxicity when compared with INH monotherapy used for anti-TB prophylaxis $[12,13]$. The occurrence of anti-TB hepatotoxicity is variable. 
In the current study, $6.1 \%$ of patients developed anti-TB DIH, an incidence less than those stated in reports available from India $(8.0-19.8 \%)$ [13] but more than those from the West (4.3\%) [14]. In Malaysia, the incidence of anti-TB DIH was reported at $9.7 \%$ and $8.7 \%[15,16]$. The variation in the incidence of anti-TB DIH observed in the current study may be due to differences in patients' characteristics, regimens used, type of monitoring, and the diagnostic criteria defining hepatotoxicity [13].

The current study comparatively assessed the sociodemographic profiles between the genders of these patients. A higher percentage of anti-TB DIH was found in male than female patients. Not surprisingly, we observed that male patients had a higher percentage of concurrent risk factors such as smoking, diabetes mellitus, and alcohol consumption which predispose to the incidence of tuberculosis. The social and cultural values may play an important role in the higher incidence of TB among men. The literature suggests that the higher incidence of TB among males might be due to their large social contacts whereas culturally women tend to stay at home or work in the field in developing countries. However, if countries are developed, such cultural and social differences may not play the same role, as both genders have high social contacts. In such cases, biological mechanisms play an important role in determining gender differences in infection rates. In a 15 -year prospective study of 280,000 subjects, it was reported that progression from infection to disease was $8.6 \%$ among men and $3.1 \%$ among women [17]. This difference may also be due to men's greater exposure to risk factors that include smoking and alcohol.

Gender differences were highly observed in many studies and it has been reported that females are at increased risk of hepatotoxicity compared to males. A study by Batool et al., (2006) [18] reported that out of 60 patients, 38 female patients had anti-TB DIH. Another study showed that 44 (44\%) males and $56(56 \%)$ females had anti-TB DIH [19]. A recent study by Alima et al. (2013) reported 17 female patients (51.5\%) who had anti-TB drug-induced hepatotoxicity and 53 (53.5\%) among the control group [10].

However, several other studies explained hepatotoxicity as a higher risk factor in males than females [20]. A study by Lee et al. showed that $84(57 \%)$ male and 64 (43\%) female patients had anti-TB DIH. Another study by Amer et al. (2010) reported males $(\mathrm{n}=75,59.5 \%)$ were more affected then females $(\mathrm{n}=51,40.5 \%)[16,21]$. Drug-induced hepatotoxicity was more common in males $(n=36,56 \%)$ than females $(n=29,44 \%)$ [22]. In this study, the incidence of anti-TB DIH is higher in male patients $(n=146,76.8 \%)$ than female patients $(n=44,23.2 \%)$. The results reflect that the incidence is higher in males which correlates to that reported by Marzuki et al. [20].

Age was divided into a younger age group ( $\leq 35$ years of age) and older age group ( $>35$ years of age) for the purpose of this analysis, based on previous studies [23, 24]. Although it has been reported that advanced age can be a risk factor for anti-TB DIH $[10,11]$, in the present study no correlation was found between age groups and the risk of developing anti-TB DIH $(\mathrm{p}=0.136)$. Also in other studies, advanced age was not a risk for anti-TB DIH $[25,26]$. In this study, 121 (79.1\%) male patients and $32(20.9 \%)$ female patients aged 35 and above developed anti-TB DIH compared to $25(67.6 \%)$ male patients and $12(32.4 \%)$ female patients below 35 years of age. The mean age for the males and females were $47.49 \pm 14.28$ and $45.0 \pm 14.96$ years, respectively.

\section{CONCLUSION}

The incidence of anti-TB DIH observed in the current study is similar to those reported from Western countries and in Malaysia. A number of factors including residence, smoking habit, alcohol consumption and intra venous drug user's patients were found to be significantly associated with anti-TB DIH. Female TB DIH patients were more likely to have TB treatment success when compared to their counterparts. Likewise, our analysis suggests that Indian ethnicity, patients with relapse tuberculosis (TB) and patients with Human Immune Virus (HIV) were less likely to have successful treatment outcomes. Intensive monitoring of patients on antiTB drugs with identified risk factors, especially during the first month of treatment, might help to identify potential hepatotoxicity in time and to withdraw drugs at the right time to prevent severe hepatotoxicity which may be fatal.

\section{DECLARATION}

The current paper is and will not be submitted elsewhere until a final decision is reached. All authors are made aware that the current manuscript is submitted to Open Medicine Journal. The manuscript has undergone English editing and grammar services by English editing Netherlands (englishediting.nl)

\section{ETHICS APPROVAL AND CONSENT TO PARTICIPATE}

Ethical clearance was secured from the School of Pharmaceutical Sciences, University Sains Malaysia. Permission to proceed with the study protocol was obtained from the Clinical Research Centre (CRC) Penang Hospital, Pulau Pinang.

\section{HUMAN AND ANIMAL RIGHTS}

No animals were used in this research. All human research procedures followed were in accordance with the ethical standards of the committee responsible for human experimentation (institutional and national), and with the Helsinki Declaration of 1975, as revised in 2013.

\section{CONSENT FOR PUBLICATION}

Not applicable.

\section{AVAILABILITY OF DATA AND MATERIALS}

The study data is extracted from Respiratory Clinic of Penang General Hospital (PGH) and Bukit Mertajam Hospital and authors have it on SPSS.

\section{FUNDING}

None. 


\section{CONFLICT OF INTEREST}

The authors declare no conflict of interest, financial or otherwise.

\section{ACKNOWLEDGEMENTS}

Declared none.

\section{REFERENCES}

[1] Wirth T, Hildebrand F, Allix-Béguec C, et al. Origin, spread and demography of the Mycobacterium tuberculosis complex. PLoS Pathog 2008; 4(9)e1000160

[http://dx.doi.org/10.1371/journal.ppat.1000160] [PMID: 18802459]

[2] World Health Organization. Treatment of tuberculosis Guidelines 2010.https://www.who.int/tb/publications/2010/9789241547833/en/

[3] Liew SM, Khoo EM, Ho BK. Tuberculosis in Malaysia: Predictors of Treatment Outcomes in A National Registry. Int J Tuberc Lung Dis 19

[4] Songhua C, Pengcheng H, Xiaomeng W, et al. Risk factors for multidrug resistance among previously treated patients with tuberculosis in eastern China: a case-control study. IJID 2013; 17(12): e1116-11120.

[5] World Health Organization. 2007.https://www.who.int/tobacco/ resources/publications/tb_tobac_monograph.pdf

[6] Ottmani SE, Uplekar MW. Gender and TB: pointers from routine records and reports. Int J Tuberc Lung Dis 2008; 12(7): 827-8. [PMID: 18544211]

[7] Alma T, Martin JB, Rob EA, et al. Antituberculosis drug-induced hepatotoxicity: Concise up-to-date review. JGH 2008; 23(2): 192-202.

[8] Frieden TR, Sterling TR, Munsiff SS, Watt CJ, Dye C. Tuberculosis. Lancet 2003; 362(9387): 887-99.

[http://dx.doi.org/10.1016/S0140-6736(03)14333-4] [PMID: 1367 8977]

[9] Vivek VB, Tyagi A, Shrivastava M, et al. Incidence of hepatotoxicity in Indian patients receiving standard multidrug anti-tubercular therapy without risk factors. CEGH 2013; 1(2): 58.

[10] Hassen Ali A, Belachew T, Yami A, Ayen WY. Anti-tuberculosis drug induced hepatotoxicity among TB/HIV co-infected patients at Jimma University Hospital, Ethiopia: nested case-control study. PLoS One 2013; 8(5)e64622

[http://dx.doi.org/10.1371/journal.pone.0064622] [PMID: 23696901]

[11] Khan AH, Israr M, Mateen O, et al. Gender Differences In The Treatment Outcomes Among Tuberculosis Patients: A Retrospective Cohort Analysis In Pakistan. WIMJ

[12] Durand F, Jebrac G, Passayre D, et al. Hepatotoxicity of antitubercular treatments. DS 1996; 15: 394-405.

[13] Pande JN, Singh SPN, Khilnani GC, Khilnani S, Tandon RK. Risk factors for hepatotoxicity from antituberculosis drugs: a case-control study. Thorax 1996; 51(2): 132-6.

[http://dx.doi.org/10.1136/thx.51.2.132] [PMID: 8711642]
[14] Lee WM. Drug-induced hepatotoxicity. N Engl J Med 1995; 333(17): 1118-27.

[http://dx.doi.org/10.1056/NEJM199510263331706] [PMID: 7565 951]

[15] Marzuki OA, Fauzi ARM, Ayoub S, Kamarul Imran M. Prevalence and risk factors of anti-tuberculosis drug-induced hepatitis in Malaysia. Singapore Med J 2008; 49(9): 688-93. [PMID: 18830542]

[16] Amer HK, Azhar SS, Hassali MA, et al. Anti-tubercular chemotherapy and drug-induced hepatitis. Health Med 2010; 536-44.

[17] World health organisation report of Global tuberculosis control 2003.http://www.who.int/gender/documents/en/TB.factsheet.pdf

[18] Batool SM, Hamid RK, Masoud S. Incidence of Hepatotoxicity due to antitubercular medicine and assessment of risk factors. Iran J Med Sci 2006; 6(1): 44-7.

[http://dx.doi.org/10.3923/jms.2006.44.47]

[19] Makhlouf HA, Helmy A, Fawzy E, El-Attar M, Rashed HA. A prospective study of antituberculous drug-induced hepatotoxicity in an area endemic for liver diseases. Hepatol Int 2008; 2(3): 353-60. [http://dx.doi.org/10.1007/s12072-008-9085-y] [PMID: 19669265]

[20] Marzuki OA, Fauzi ARM, Ayoub S, Kamarul IM. Prevalence and risk factors of anti-tuberculosis drug-induced hepatitis in Malaysia. Singapore Med J 2008; 49(9): 688-93. [PMID: 18830542]

[21] Watt AH. Spontaneous reporting of suspected adverse drug reactions. Br J Clin Pharmacol 1992; 33(4): 461-2.

[http://dx.doi.org/10.1111/j.1365-2125.1992.tb04070.x] [PMID: 1576 073]

[22] Jaiprakash H, Narayana S, Mohanraj J. Drug-induced hepatotoxicity in a tertiary care hospital in rural South India. N Am J Med Sci 2012; 4(2): $90-3$

[http://dx.doi.org/10.4103/1947-2714.93385] [PMID: 22408755]

[23] Ungo JR, Jones D, Ashkin D, et al. Antituberculosis drug-induced hepatotoxicity. The role of hepatitis $\mathrm{C}$ virus and the human immunodeficiency virus. Am J Respir Crit Care Med 1998; 157(6 Pt 1): 1871-6.

[http://dx.doi.org/10.1164/ajrccm.157.6.9711039] [PMID: 9620920]

[24] Lee BH, Koh WJ, Choi MS, et al. Inactive hepatitis B surface antigen carrier state and hepatotoxicity during antituberculosis chemotherapy. Chest 2005; 127(4): 1304-11.

[http://dx.doi.org/10.1016/S0012-3692(15)34481-0] [PMID: 1582 1209]

[25] Sharifzadeh M, Rasoulinejad M, Valipour F, et al. Evaluation of patient-related factors associated with causality, preventability, predictability and severity of hepatotoxicity during antituberculosis treatment. Pharmacol Res 2005; 51: 353-8.

[http://dx.doi.org/10.1016/j.phrs.2004.10.009] [PMID: 15683749]

[26] Javadi MR, Shalviri G, Gholami K, Salamzadeh J, Maghooli G, Mirsaeedi SM. Adverse reactions of anti-tuberculosis drugs in hospitalized patients: incidence, severity and risk factors. Pharmacoepidemiol Drug Saf 2007; 16(10): 1104-10. [http://dx.doi.org/10.1002/pds.1468] [PMID: 17823987]

C) 2019 Nadarajah et al.

This is an open access article distributed under the terms of the Creative Commons Attribution 4.0 International Public License (CC-BY 4.0), a copy of which is available at: (https://creativecommons.org/licenses/by/4.0/legalcode). This license permits unrestricted use, distribution, and reproduction in any medium, provided the original author and source are credited. 